\title{
AN OCCURRENCE OF MONAZITE IN PUUMALA, EASTERN FINLAND
}

\author{
Ilmari Haapala, Pentti Ervamaa, Arvo Löfgren and Pentti Ojanperä \\ Geological Survey of Finland, Otaniemi
}

\begin{abstract}
A monazite occurrence consisting of three monazite-bearing biotite-rich veins is described. The veins have pegmatitic affinities but are very inhomogeneous. They are located in Precambrian migmatitic cordierite-garnet gneiss or between gneiss and pegmatite. In biotite-rich accumulations the monazite content may be about 10 volume per cent. The chemical analysis, unit cell dimensions, optical properties, magnetic susceptibility and specific gravity of monazite are presented. A comparison is made with monazite deposits of migmatite type.
\end{abstract}

\section{Introduction}

In connection with the exploration work carried out by the Geological Survey in eastern Finland in the summer of 1958, radiometric studies were done with a scintillometer fitted on a car. During the surveys a clear radioactive anomaly was recorded near the Karhukoski cabin in the eastern part of the parish of Puumala, at long. $28^{\circ} 41^{\prime} \mathrm{E}$ and lat. $61^{\circ} 30^{\prime} \mathrm{N}$. An anomaly was also recorded in the same locality as a result of airborne scintillometric surveys. Later in the same summer one of the writers (P. E.) with his assistants carried out detailed radiometric studies in the same place. He drew a geological map of the occurrence (Fig. 1) and wrote a report concerning it. The radioactive rock was observed to be a monazite-bearing biotite-rich inhomogeneous rock with pegmatitic affinities and occurring as veins in Precambrian migmatitic cordierite-garnet gneiss. In the summer of 1968 two of the authors (I. H. and P. E.) carried out further studies in the area. The X-ray studies and most of the other detailed mineralogy of the occurrence was worked out by I. H., who also compiled the manuscript. The chemical analysis of the monazite was made by A. L. and P. O.

\section{Geology}

The main rock of the area is a migmatitic cordierite-garnet gneiss. It contains as chief minerals quartz, cordierite, microcline, biotite, plagioclase $\left(A n_{15-20}\right)$ and almandine. Sillimanite, chlorite, opaque minerals, graphite, monazite, apatite and zircon occur in small amounts, occasionally also andalusite. The gneisses of the region are described in more detail by Hackman (1933, pp. 21-26) in the explanatory text to the 1: 400000 petrological map. 


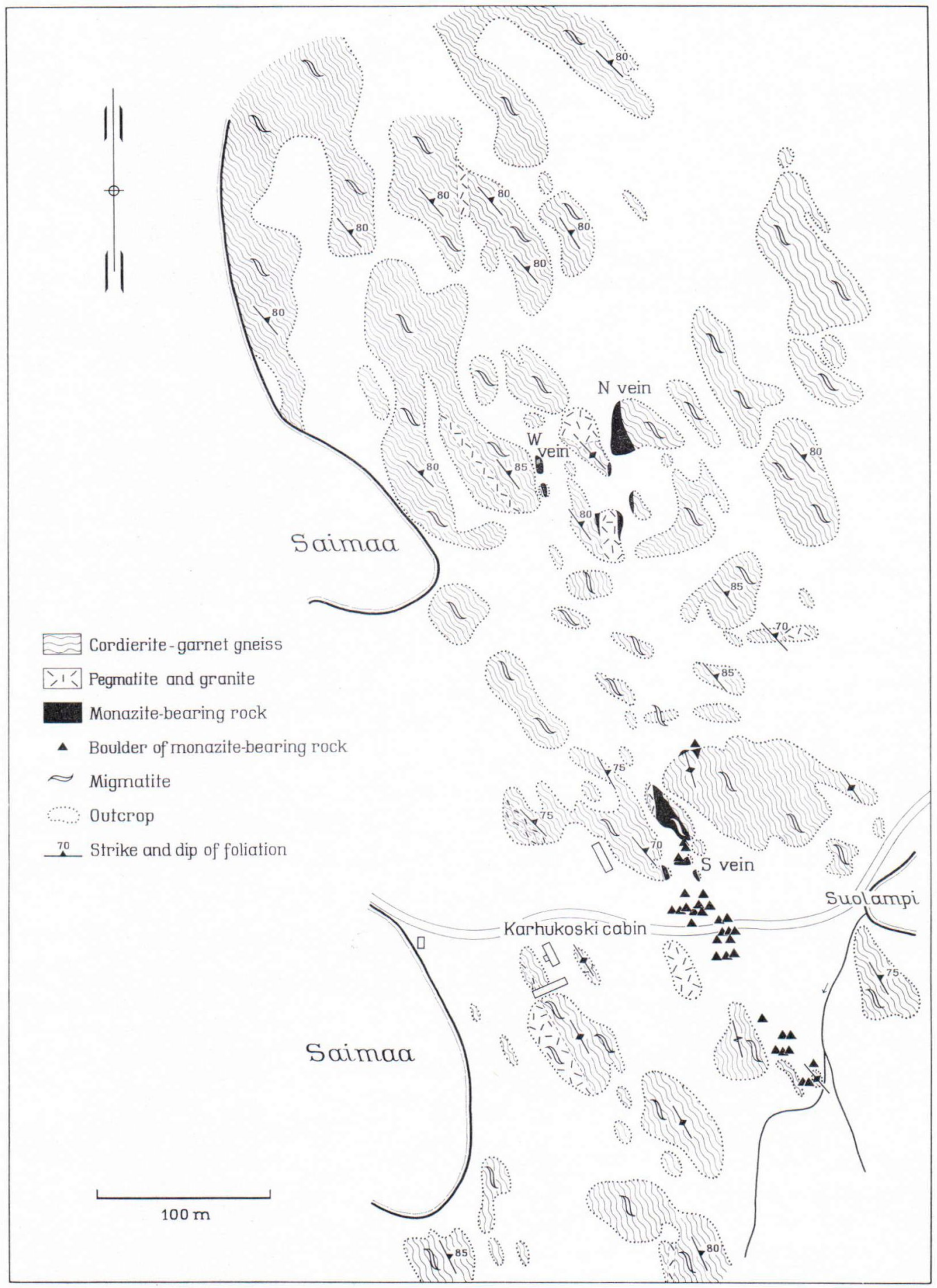

Fig. 1. Map of the outcrops in the Karhukoski area, Puumala. Mapped by Pentti Ervamaa. 


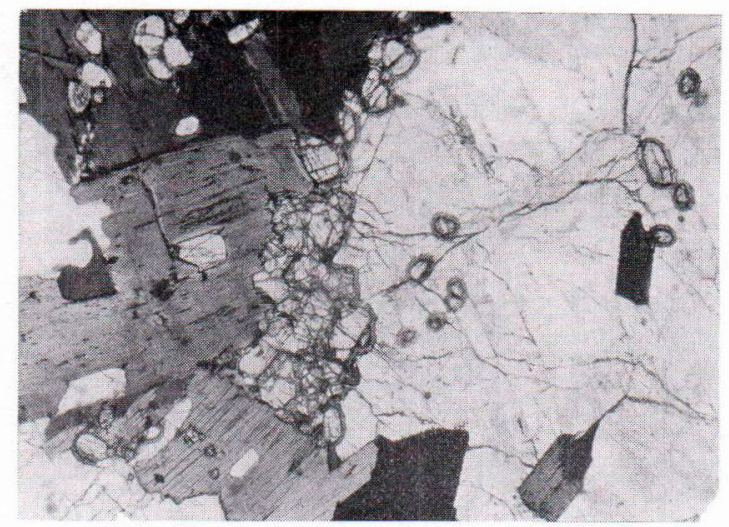

Fig. 2. Monazite-bearing rock. The light gray mineral is plagioclase. Crossed nicols. Magn. $30 \times$.

There are abundant reddish granitic and pegmatitc veins and lenses in the gneiss. Only the largest of them are marked on the geological map (Fig. 1). Most of the veins strike parallel to the foliation of the gneiss, but some are clearly discordant. Partly replaced schist fragments are common. The main constituents of the granitic and pegmatitic rocks are microcline, quartz, plagioclase $\left(\mathrm{An}_{22-26}\right)$, muscovite and/or biotite. The accessories are apatite, chlorite, almandine (at the contacts), opaque minerals, and rarely black tourmaline, andalusite and graphite. Andalusite occurs as beautiful red prisms in two discordant pegmatite veinlets about $150 \mathrm{~m}$ NW of the Karhukoski cabin.

The radioactive rock occurs as vein-like bodies in cordierite-garnet gneiss or between gneiss and pegmatite. Three veins of notable size have been found and called, according to their location, the $\mathrm{S}$ vein, the $\mathrm{N}$ vein and the $\mathrm{W}$ vein. According to the observations made on the outcrops and the radiometric studies, the approximate sizes of the veins are:

the $S$ vein: width $5-10 \mathrm{~m}$, length $\gtrsim 60 \mathrm{~m}$ the $\mathrm{N}$ vein: » $10 \mathrm{~m}$, » $70 \mathrm{~m}$ the W vein: » $1-5 \mathrm{~m}$, » $20 \mathrm{~m}$

The $\mathrm{S}$ vein can be followed for ca. $60 \mathrm{~m}$ in the outcrops, but as a field scattered with boulders

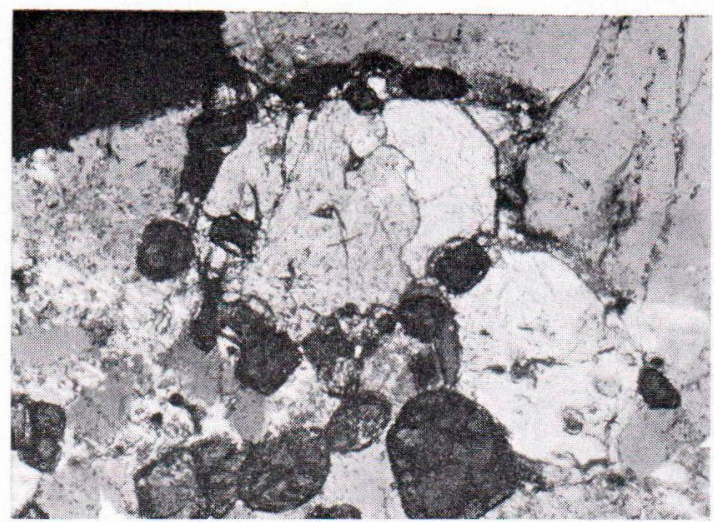

Fig. 3. Altered, nearly isotropic zircon crystals (dark gray) surrounding larger monazite crystals (light gray). The medium gray mineral is plagioclase. Oblique nicols. Magn. $130 \times$.

(Fig. 1) it can be traced for ca. $200 \mathrm{~m}$. Because the glacial drift direction in the area is the same as the strike of the vein, the length of the boulder field need not be the length of the vein.

The radioactive rock is more small-grained (grain size $0.3-2 \mathrm{~cm}$ ) and more inhomogeneous than the normal reddish pegmatite (grain size $0.5-10 \mathrm{~cm})$. The contact with the gneiss is generally sharp. The contact between the radioactive rock and the pegmatite may be sharp, but usually these rocks grade into each other over a distance of $0.5 \mathrm{~m}$. Disregarding the genesis of the pegmatites in that area, it can be noted that, at least in the case of the $\mathrm{N}$ vein, the radioactive rock seems to form spatially a more or less migmatitic wall zone of the pegmatite.

The main minerals of the radioactive rock are plagioclase $\left(\mathrm{An}_{28-34}\right)$, quartz, biotite and $\mathrm{mi}$ crocline. Also monazite occurs in considerable quantities, and most abundantly in the biotiterich parts of the rock. Biotite is very inhomogeneously distributed. It is the main mineral in the elongated radioactive zones arranged parallel to the contacts. It often occurs as fairly irregular accumulations. Some of the bands and accumulations consist essentially of biotite and monazite, the amount of monazite being locally about 10 volume per cent (more than 15 weight per cent). In biotite-poor varieties the amount of monazite 


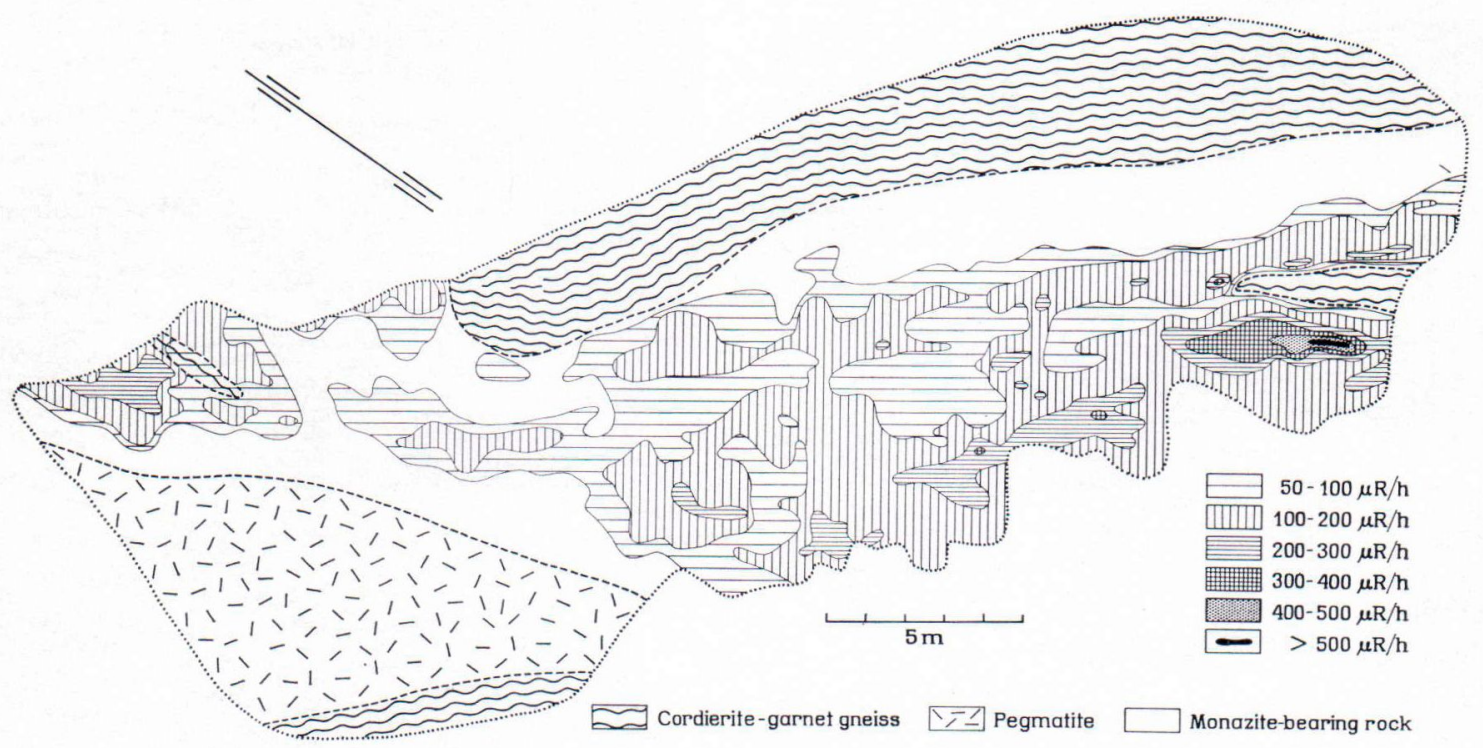

Fig. 4. Distribution of radioactivity on an outcrop of the $\mathrm{S}$ vein.

is much smaller. According to integration analyses it is of the order of $2-6$ volume per cent, or even lower. Monazite occurs partly as inclusions in biotite, partly on the borders of the biotite crystals (Fig. 2) and partly entirely outside the biotite plates. The crystals are well-formed with grain size of $0.05-0.5 \mathrm{~mm}$. The colour is yellowish brown. A yellow earthy alteration product around the monazite crystals is common. Often the grains are surrounded by strongly altered zircon crystals (Fig. 3).

As accessories the radioactive rock also contains ilmenite, magnetite, garnet, green spinel, chalcopyrite, pyrrhotite, arsenopyrite, anatase and graphite. These minerals were identified by $\mathrm{X}$-ray methods from a heavy mineral fraction. According to an electron probe microanalysis made by Mr. Jaakko Siivola, Lic. Phil., the composition of the garnet is $\mathrm{Alm}_{75} \mathrm{Pyr}_{15} \mathrm{Spe}_{7} \mathrm{GrO}_{3}$. The spinel is gahnite-hercynite with $\mathrm{Zn}: \mathrm{Fe} \sim 1: 1$. Monazite and zircon are the only singnificantly radioactive minerals identified. The radioactivity of the rock is obviously caused almost exclusively by the thorium-bearing monazite.
There are also schist fragments, which are only very weakly radioactive, in the monazite-bearing rock.

\section{Radiometric Studies}

For the purpose of making more accurate radiometric studies in the neighbourhood of the radioactive veins, a $700 \mathrm{~m}$ long base line was staked out in the direction $\mathrm{N} 07^{\circ} \mathrm{W}$. The measurements were made along cross lines perpendicular to the main line, the spacings of the cross lines bein 20 or $10 \mathrm{~m}$ and those of the measurement points $5 \mathrm{~m}$. The extent of the studied area was $300 \mathrm{~m} \times 700 \mathrm{~m}$.

Because the veins proved to be very inhomogenous with regard to their radioactivity, detailed radiometric studies were made on the two most active veins, the $\mathrm{S}$ vein and the $\mathrm{W}$ vein. The measurements were made with a Victoreen scintillometer. The counting range of $100000 \mathrm{c} / \mathrm{min}$ $(500 \mu \mathrm{R} / \mathrm{h})$ of this scintillometer was in some points insufficient. During the measurements the 
scintillometer recorder was held about $10 \mathrm{~cm}$ above the rock surface. Fig. 4 presents the distribution of radioactivity in one part of the $S$ vein.

The radioactivity of the monazite bearing rock varies between 30 and $1000 \mu \mathrm{R} / \mathrm{h}$. The activity of the cordierite-garnet gneiss is $10-$ $16 \mu \mathrm{R} / \mathrm{h}$ and that of the usual pegmatite and granite $12-25 \mu \mathrm{R} / \mathrm{h}$.

\section{Monazite}

Monazite was separated for chemical analysis and other mineralogical studies from a sample taken from the most radioactive part of the $S$ vein. Magnetite and pyrrhotite were removed by using a hand magnet and a Franz isodynamic separator. Zircon, chalcopyrite, ilmenite, spinell, garnet and other silicates were removed with a heated Clerici solution (sp. gr. 4.8). The final concentrate contained less than 0.5 per cent impurities. The chemical composition and the physical properties given in Table 2 were determined for this material.

The unit cell dimensions were determined from the $b$ - and $c$-axis zero-level precession photographs of a small crystal, using Zr-filtered Mo radiation. The films were calibrated with the reflections of a silicon crystal oriented beforehand and exposed on the same films with the same instrument settings. Also $a$-axis rotation and zero-level Weissenberg photographs were taken from the crystal, using Ni-filtered $\mathrm{Cu}$ radiation. The indexing of the powder pattern and the calculation of the interplanar spacings (Table 1) were based on the crystallographic data obtained from the single-crystal study. The $\mathrm{X}$-ray powder diffraction measurements were made with a Philips wide-range goniometer by using Ni-filtered $\mathrm{Cu}$ radiation, a scanning speed of $1^{\circ}$ per 4 minutes and silicon as an internal standard. The measured $2 \Theta$ values are the averages of two recordings.

The magnetic susceptibility was determined with a magnetic susceptibility bridge, Model
TABLe 1

$\mathrm{X}$-ray powder diffraction data for monazite from Puumala. Ni-filtered $\mathrm{Cu}$ radiation $(\lambda \mathrm{Cu} K \alpha=1.54178 \AA)$, silicon as an internal standard

\begin{tabular}{|c|c|c|c|c|}
\hline$b k l$ & $I$ & $2 \Theta_{\text {meas }}$ & $d_{\text {meas. }}$ & $d_{\text {calc. }}$ \\
\hline$\overline{1} 01$ & 15 & 16.99 & 5.219 & 5.200 \\
\hline 110 & 10 & 18.48 & 4.801 & 4. 799 \\
\hline 011 & 10 & 18.90 & 4.695 & 4.683 \\
\hline$\overline{1} 11$ & 10 & 21.23 & 4.185 & 4.177 \\
\hline 101 & 20 & 21.64 & 4.107 & 4.098 \\
\hline 111 & 10 & 25.16 & 3.539 & 3.537 \\
\hline 020 & 30 & 25.37 & 3.511 & 3.502 \\
\hline 200 & 80 & 27.05 & 3.296 & 3. 294 \\
\hline 120 & 100 & 28.84 & 3.096 & 3.092 \\
\hline 210 & 20 & 29.95 & 2.983 & 2.981 \\
\hline 012 & 50 & 31.10 & 2.876 & 2.872 \\
\hline$\overline{1} 12$ & & & & 2.867 \\
\hline$\overline{2} 02$ & 10 & 34.41 & 2.606 & 2.601 \\
\hline 112 & & & & 2.448 \\
\hline$\overline{2} 12$ & 15 & 36.77 & 2.444 & 2.439 \\
\hline 220 & 5 & 37.50 & 2.398 & 2.399 \\
\hline 031 & 20 & 41.22 & 2.190 & 2.189 \\
\hline$\overline{103}$ & & 42.02 & 2.150 & 2.152 \\
\hline$\overline{3} 11\}$ & $20 \mathrm{~b}$ & 42.32 & 2.136 & 2.137 \\
\hline$\overline{2} 22$ & $<5$ & 43.32 & 2.089 & 2.088 \\
\hline 131 & 10 & 44.63 & 2.030 & 2.028 \\
\hline 212 & 15 & 46.18 & 1.966 & 1.967 \\
\hline$\overline{2} 31$ & 10 & 47.96 & 1.897 & 1.896 \\
\hline 103 & & & & 1.877 \\
\hline 032 & 20 & 48.56 & 1.875 & 1.875 \\
\hline 320 & 15 & 48.98 & 1.860 & 1. 861 \\
\hline 040$]$ & & & & 1.751 \\
\hline 132$\}$ & $15 b$ & 52.59 & 1.740 & 1.741 \\
\hline$\overline{2} 32$ & & & & 1.737 \\
\hline 140 & 15 & 54.20 & 1.692 & 1.692 \\
\hline
\end{tabular}

MS-2. The mean mass susceptibility $\left(38 \cdot 10^{-6}\right.$ $\mathrm{cm}^{3} / \mathrm{g}$ ) is of the same order as that of hematite. The high susceptibility of monazite derives from the atomic properties of the rare earths (Murata et al., 1953). The refractive indices were determined in $\mathrm{Na}$ light by the immersion method. The optic angle was measured from a thin section with a universal stage.

Before the wet chemical analysis (P. O.) and the spectrochemical analysis (A. L.) the Puumala monazite was qualitatively studied with an X-ray fluorescence spectrograph by Mr. Väinö Hoffrén, Mag. Phil.

The thorium content of monazite varies strongly depending on the metamorphic facies 
TABLE 2

Chemical analysis and physical properties for the monazite from Puumala. Spectrochemical analysis (thorium and rare earths) by Arvo Löfgren, wet chemical analysis by Pentti Ojanperä

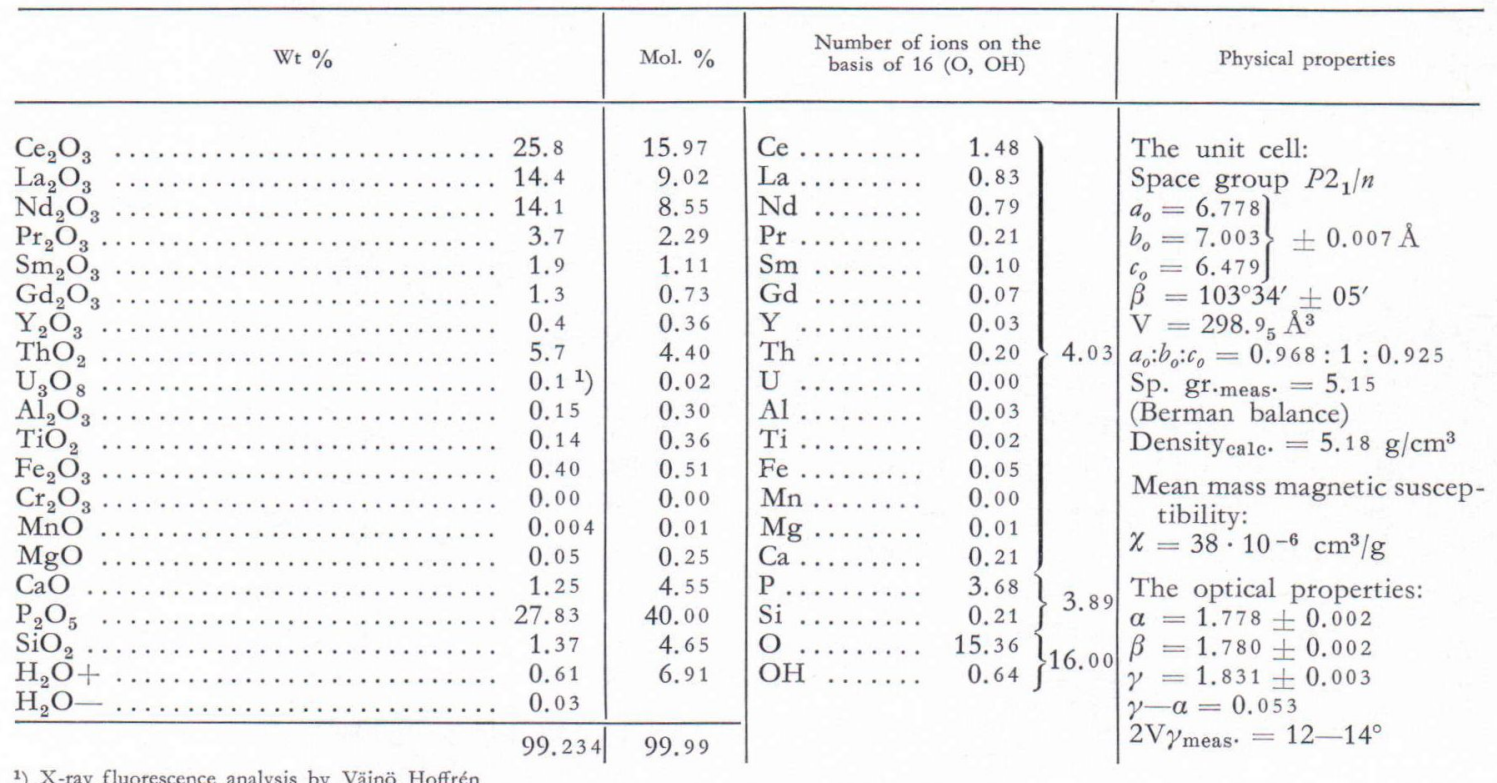

and the nature of the igneous rock in which the mineral occurs (Overstreet, 1967). The $\mathrm{ThO}_{2}$ content (5.7 weight per cent) of the Puumala monazite is of the same order as is common in granites and rocks metamorphosed in the amphibolite facies. In pegmatites, the $\mathrm{ThO}_{2}$ content is usually higher. The content of thorium is almost equivalent to the contents of silica and calcium.

The distribution of rare earths is within the range generally observed for monazites occurring in granites, pegmatites and metamorphic rocks (Vlasov, 1966; Overstreet, op. cit.). Calculated to 100 , the proportions of the rare-earth elements are: $\mathrm{Ce}$ 42.1, La 23.7, Nd 22.5, Pr 6.0, Sm 2.9, Gd 1.9 and $\mathrm{Y} \mathrm{0.9}$. The sum $\mathrm{Ce}+\mathrm{La}+\mathrm{Pr}$ is 71.8. Using the diagram relating $\mathrm{Ce} /(\mathrm{Nd}+\mathrm{Y})$ $(1.80)$ to the sum Ce $+\mathrm{La}+\operatorname{Pr}$ (Murata et al., 1957), the estimated sum 71 closely agrees with the sum calculated from the analysis.

The unusually low refractive indices are probably due to the high content of calcium. Similarly calcium lowers the specific gravity.
The calculated density is obtained from the chemical analysis and unit cell dimensions by assuming $16(\mathrm{O}, \mathrm{OH})$ per unit cell. If $\mathrm{H}_{2} \mathrm{O}+$ is omitted as unessential and the density is calculated on the basis of $16(\mathrm{O})$, the value should be 5.25 .

A differential thermal analysis of the Puumala monazite gave a practically featureless curve between $100^{\circ}$ and $1000^{\circ} \mathrm{C}$, indicating a scantity or absence of alteration products (see Molloy, 1959). A thermogravimetric analysis showed a nearly linear weight loss of 0.425 per cent between $200^{\circ}$ and $1000^{\circ} \mathrm{C}$.

\section{Comparison with other monazite deposits}

The Karhukoski monazite occurrence has many similarities with the radioactive deposits which Heinrich (1958, p. 222) and Lang et al. (1962, p. 57) called migmatite deposits. Rare earth and thorium deposits of this type are obviously quite widespread, although studies of 
them are scarce. As Heinrich (op. cit., p. 223) pointed out, the distinction between the ordinary pegmatite deposits and the migmatite deposits is often arbitrary. Mineralogically, however, the pegmatitic monazite deposits are usually characterized by the presence of complex oxide minerals (e.g. niobo-tantalates), gadolinite, etc. Exceptions of this rule are summarized by Heinrich (op. cit., p. 216). The rare earth minerals occurring in the migmatite deposits are monazite, thorite, uranothorite, allanite, xenotime and brennerite (Olson and Overstreet, 1964 , p. 20). Structurally the migmatite deposits are more inhomogeneous and more small-grained than the normal pegmatites. They usually occur in strongly injected and thoroughly migmatized biotite gneisses. Typical examples of migmatite monazite deposits were described by Davidson (1956) from Travancore, India; by Heinrich (op. cit., p. 222) from the Baverlodge area, Saskatchewan; by Young and Sims (1961) from the Central City area, Colorado; and by Overstreet (1967, pp. 184-251) from the southwestern United States (Piedmont province). In Travancore the monazite occurrence is in a garnet-bearing biotite schist located in a belt of pegmatite injection. It is nearly $100 \mathrm{ft}$. wide and extends with interruptions for nearly a mile. Five samples of the richer ore averaged 17.9 per cent monazite (Davidson, op. cit.). In the Baverlodge area, one type of migmatite deposit consists chiefly of biotite and monazite, the amount of monazite being locally 25 per cent of the narrow segregations (Heinrich, loc. cit.). In the Central City area monazite and xenotime occur abundantly in three localities in migmatized biotite gneiss. These minerals are interpreted as having concentrated at their present sites during migmatization processes, the rare earths and phosphorus having been selectively mobilized by granitic fluids from the biotite gneiss country rock (Young and Sims, op. cit.). From the Piedmont province, the southwestern United States, monazite occurrences have been mined in a pegmatite-impregnated biotite schist at Hickory Creek and at Carpenter Knob in Cleaveland County, North Carolina (Overstreet, loc. cit.).

Owing to the inhomogeneous nature and small size of the richer parts, the Karhukoski deposit in Puumala is of no economic importance at present. But it may be regarded as an intimation of greater undiscovered rare earth and thorium deposits possibly occurring in the area.

Acknowledgements - The writers are grateful to Mr. Väinö Hoffrén, Mag. Phil., for the X-ray fluorescence analysis; to Mr. Jaakko Siivola, Lic. Phil., for the electron probe microanalyses; to Mr. Kalevi Punakivi, Mag. Phil., for the differential thermal analysis and the thermogravimetric analysis of monazite; to Mr. Risto Puranen for the magnetic susceptibility determination; to Mr. Erkki Halme for taking the photographs and to Miss Karin Dahl for drawing the maps. Cordial thanks are also due to Dr. Atso Vorma for the critical reading of the manuscript.

\section{REFERENCES}

Davidson, C. F. (1956) The economic geology of thorium. Mining Mag. 94, pp. 197-208.

HACKman, V. (1933) Kivilajikartan selitys D 2, Savonlinna. Suomen Geologinen yleiskartta 1: 400000 .

Heinrich, E. WM. (1958) Mineralogy and geology of radioactive raw materials. McGraw-Hill Book Company, Inc., New York, Toronto and London.

Lang, A. H., Griffith, J. W. and Steacy, H. R. (1962)
Canadian deposits of uranium and thorium. Can. Geol. Surv., Econ. Geol. Ser. 16, pp. 1-324.

Molloy, M. W. (1959) A comparative study of ten monazites. Am. Mineral. 44, pp. 510-532.

Murata, K. J., Rose, H. J. Jr. and Carron, M. K. (1953) Systematic variation of rare earths in monazite. Geochimica et Cosmochimica Acta 4, pp. 292-300. Murata, K. J., Rose, H. J. Jr., Carron, M. K. and 
Glass, J. J. (1957) Systematic variation of rare-earth elements in cerium-earth minerals. Geochimica et Cosmochimica Acta 11, pp. 141-161.

Olson, J. C. and Overstreet, W. C. (1964) Geologic distribution and resources of thorium. U.S. Geol. Surv. Bull. 1204, pp. 1-61.

Overstreet, W. C. (1967) The geologic occurrence of monazite. U.S. Geol. Surv. Prof. Paper 530, pp. $1-$ 327.

Vlasov, K. A. (editor) (1966) Geochemistry and mine- ralogy of rare elements and genetic types of their deposits. Vol. II. Mineralogy of rare elements. Translated from the Russian by Z. Lerman. Israel Program for Scientific Translations, Jerusalem.

Young, E. J. and Sims, P. K. (1961) Petrography and origin of xenotime and monazite concentrations, Central City district, Colorado. U.S. Geol. Surv. Bull. 1032-F, pp. 273-297.

Manuscript received, November 6, 1968. 